\title{
SIKAP MEMBERI PERSEMBAHAN \\ MENURUT INJIL MARKUS 12:41-44
}

David Susilo Pranoto

davidsusilopranoto@sttab.ac.id

\begin{abstract}
This paper is titled" Attitude to Give Offerings According to the Gospel of Mark 12: 41-44 ". Mark's Gospel was written by Mark himself and this Gospel of Mark is the earliest Gospel written, which is between 65 and 70 AD before the Temple in Jerusalem was destroyed and Mark's Gospel is also the shortest of the four Gospels. This book was shown to the Jews to introduce Christ as a servant. Specifically the Gospel of Mark 12: 41-44 tells how Jesus showed His disciples the attitude of the rich and the widows of the poor in giving offerings. This shows that Jesus wanted to tell everyone and specifically to the students how the right attitude in giving offerings. The text Jesus shows about the attitude of the rich and poor widows in making offerings in the Temple. In addition, in the context of the Gospel of Mark 12: 41-44, Jesus showed His disciples the right attitude in offering. Jesus' purpose here is to direct the attention of His disciples to the poor widow. The poor widow gives more offerings than the offerings of rich people, because she gives from her shortcomings while rich people give from abundance. So through this article we can open the understanding of believers to have the right attitude to offer.
\end{abstract}

Keywords: Attitude, Offerings.

ABSTRAKSI: Makalah ini berjudul "Sikap Memberi Persembahan Menurut Injil Markus 12:41-44". Injil Markus di tulis oleh Markus sendiri dan Injil Markus ini merupakan Injil yang paling awal ditulis, yaitu antara tahun 65 dan 70 M sebelum Bait Allah di Yerusalem dihancurkan dan Injil Markus juga merupakan Kitab yang terpendek di antara keempat Injil. Kitab ini ditunjukkan kepada orang Yahudi untuk memperkenalkan Kristus sebagai hamba. Secara khusus Injil Markus 12 : 41- 44 menceritakan bagaimana Yesus menunjukkan kepada murid-murid-Nya tentang sikap orang kaya dan janda miskin dalam memberi persembahan. Hal ini menunjukkan bahwa Yesus ingin memberitahukan kapada semua orang dan secara khusus kepada para murid bagaimana sikap yang benar dalam memberi persembahan. Teks tersebut Yesus menunjukkan tentang sikap orang kaya dan janda miskin dalam memberi persembahan di Bait Allah. Selain itu dalam konteks Injil Markus 12:41-44 ini Yesus menunjukkan kepada murid-murid-Nya tentang sikap yang baik dalam memberi persembahan. Tujuan Yesus disini ialah untuk mengarahkan perhatian murid-murid-Nya kepada janda miskin. Janda miskin tersebut memberi persembahan lebih banyak dibandingkan dengan persembahan persembahan orang-orang kaya, sebab ia memberi dari kekurangannya sementara orang-orang kaya memberi dari kelimpahan. Jadi melalui tulisan ini dapat membuka pengertian orang percaya agar memiliki sikap memberi persembahan yang benar.

Kata Kunci: Sikap, Persembahan. 


\section{LATAR BELAKANG}

Memberi bukanlah perkara yang mudah dalam kehidupan manusia, apa lagi memberikan bantuan baik itu materi, tenaga, pikiran dan jasa kepada sesama yang tidak dikenal atau tidak ada hubungan keluarga. Sebagai orang Kristen harus belajar untuk memberi, namun memberi bukan untuk mendapat keuntungan, tetapi memberi untuk mengembangkan pelayanan Tuhan melalui gereja. Selajutnya menjadi orang Kristen harus memiliki hati yang tulus dalam memberi dan juga pengorbanan bagi pelayanan Tuhan. Memberi persembahan merupakan suatu kewajiban sebagai umat Allah, sebab itu adalah perintah Tuhan bagi umat-Nya (Luk. 6:38). Alkitab menjelaskan bahwa memberi persembahan itu sangat penting sebab Yesus berkata "adalah lebih berbahagia memberi dari pada menerima (Kpr. 20:35).

Setiap orang yang memberi persembahan harus memiliki sikap yang benar untuk melakukannya, sebab itu yang diinginkan Tuhan. Yesus sendiri yang menjadi contoh dalam hal memberi yang sangat sempurna dan Paulus juga menjelaskan bahwa "karena kamu telah mengenal kasih karunia Yesus Kristus bahwa Ia yang oleh karena kamu menjadi miskin, sekali pun Ia kaya, supaya kamu menjadi kaya oleh karena kemiskinanNya" (2 Kor. 8:9). Dengan demikian memberi berdasarkan Alkitab haruslah merupakan tindakan yang secara naruliah keluar dari kasih yang ada di dalam hati kita, artinya bahwa orang yang sudah menerima kasih karunia Allah harus memberi kepada orang lain, sama seperti Tuhan Yesus telah memberikan-Nya kepada umat-Nya. ${ }^{1}$

Wright menjelaskan dalam ikhtisarnya memberi persembahan yaitu sebuah persembahan tidak diukur menurut jumlah yang dipersembahkan, tetapi menurut jumlah yang tersisa bagi pemberi, bukan jumlah uang, melainkan suasana hati yang penting, memberi dengan sungguh-sungguh adalah memberi semuanya, pemberian harus sesuai dengan harta milik pemberi, memberi merupakan kewajiban, juga bagi orang yang paling miskin. $^{2}$

Berdasarkan pandangan Wright tersebut dapat disimpulkan bahwa dalam memberi persembahan harus dilakukan dengan hati yang ikhlas dan tidak bersungut-sungut. Memberi persembahan bukan berbicara dengan jumlah tetapi yang terpenting dalam hal memberi adalah sikap atau tindakan dalam memberi persembahan tersebut.

Kitab Injil menjelaskan juga tentang persembahan dalam bentuk persepuluhan. Persembahan tersebut tidak akan cukup mewakili seluruh

\footnotetext{
${ }^{1}$ Ibid., 315

${ }^{2}$ Jakob Van Bruggen, Markus Injil Menurut Petrus, (Jakarta : BPK Gunung Mulia, 2011), 441
} 
kehidupan sehari-hari, sebab persembahan ini harus disertai dengan sikap hidup yang kristiani yakni peduli akan kasih dan keadilan. Memberi persembahan dalam bentuk materi bukan yang terutama, melainkan dengan sikap hidup yang baik dihadapan Allah. Memberi persembahan lebih di arahkan kepada hal-hal yang mulia seperti keadilan dan kasih (Luk. 11:42). Memberi sedekah berarti membuat Allah bersukacita bila tindakan tersebut disertai dengan pengampunan dan rasa terimakasih kepada Allah. Memberi persembahan kepada Allah akan mengasilkan tindakan yakni rasa terima kasih dan ucapan syukur. ${ }^{3}$

Berdasarkan penjelasan di atas, penulis bahwa dalam memberi persembahan bukan masalah nilai yang akan diberikan, tetapi yang terpenting dalam memberi persembahan tersebut yaitu sikap atau tindakan dalam memberi persembahan tersebut. Alkitab mengajarkan bahwa dalam hal memberi persembahan janganlah seperti orang munafik artinya jika seseorang memberi persembahan janganlah diketahui oleh orang lain. Selanjutnya memberi sedekah merupakan hal yang sangat baik dan sangat menyenangkan hati Tuhan jika dilakukan dengan tindakan yang rendah hati dan tulus melakukannya. Seperti janda miskin yang hanya mempunyai sedikit harus memberi sedekah dari yang sedikit itu. Mereka yang hanya hidup dengan bekerja dengan nafkah yang hanya cukup untuk sehari harus memberi kepada mereka yang membutuhkannya (Ef. 4:28). Walaupun yang diberikan itu untuk tujuan yang baik hanya sedikit tetapi jika diberikan sesuai dengan kemampuan, dan diberikan dengan hati yang tulus, maka pemberian tersebut akan diterima oleh Kristus yang telah memerintahkan agar seseorang memberi sesuai dengan apa yang dimiliki, dan bukan dari apa yang tidak dimiliki artinya bahwa memberi harus sesuai dengan kemampuan. ${ }^{4}$

Kain adalah salah satu contoh dalam Alkitab orang yang fasik, hidupnya jahat dan dikuasai oleh dunia dan kedagingan yang bertakhta akhirnya itu korban persembahannya kekejian bagi Tuhan (Ams. 15:8), dan persembahannya yang tidak sungguh-sungguh (Yes. 1:13). Allah tidak mengindahkan persembahan Kain sebab persembahannya tersebut tidak sungguh-sungguh ia memberikannya kepada Tuhan dan hanya sebagian yang ia persembahkan kepada Tuhan. Sedangkan Habel adalah orang benar (Mat. 23:35) hatinya lurus dan hidupnya saleh, ia salah seorang yang dipandang oleh wajah Allah (Mzm. 11:7), dan doanya juga dapat berkenan kepada Tuhan (Ams. 15:8). Allah mengindahkannya sebagai orang kudus oleh sebab itu Allah juga mengindahkan korban persembahannya sebagai korban persembahan yang kudus (Ibrani 11:4) menjelaskan bahwa korban

\footnotetext{
${ }^{3}$ Thomas Suyasno, Memberi Makna Hidup, (Jakarta : Prestasi Pustakaraya, 2009), 103

${ }^{4}$ Matthew Henry,Tafsiran Injil Markus, (Surabaya : Momentum Christian Literature, 2007), 287
} 
persembahan Habel adalah korban yang lebih baik dari pada korban Kain. Sebab korban persembahan Kain hanyalah korban pengakuan yang dipersembahkan kepada Allah, tetapi Habel membawa korban persembahan penghapus dosa, yang darahnya dicurahkan untuk penghapus dosa dan mengakui dirinya sebagai orang yang berdosa. ${ }^{5}$

Selanjutnya perbedaan antara persembahan Habel dan persembahan Kain yaitu Habel memberikan persembahan dengan iman artinya ia mempersembahkannya dengan mata yang tertuju kepada Tuhan sebagai pedomannya, dan kemuliaan Allah sebagai tujuannya dan ia percaya bahwa persembahannya itu tidak sia-sia. ${ }^{6}$ Jadi berdasarkan penjelasan tersebut dalam memberi persembahan kepada Tuhan harus disertai dengan iman dan dengan mata yang tertuju kepada Tuhan seperti Habel dan juga memiliki tujuan yang positif dalam memberi persembahan tersebut.

Begitu juga Nuh mempersembahan korban persembahannya kepada Tuhan sebagai wujud ucapan syukur atas kebaikan Allah kepadanya, ia mendirikan Mezbah dan ia tidak berbuat apa pun tanpa petunjuk dan perintah khusus dari Allah. Ia dipanggil Allah untuk masuk ke dalam bahtera, dan panggilan lain untuk keluar dari bahtera tersebut. Tetapi karena mezbah dan korban bakaran sudah merupakan ketetapan ilahi dan ibadah, akahirnya ia tidak menunggu perintah khusus untuk mengungkapkan rasa syukurnya kepada Tuhan, artinya Nuh mempunyai inisiatif sendiri untuk mempersembahakan korban bakaran kepada Tuhan. Sebab itu orang-orang yang sudah menerima belas kasihan dari Allah harus menjadi orang yang utama dalam mengucap syukur, dan melakukannya bukan dengan paksa, tetapi dengan suka rela. ${ }^{7}$

Persembahan juga dapat diartikan sebagai persembahan persepuluhan, dan persembahan tersebut merupakan perintah Allah kepada bangsa Israel dan persembahan tersebut di ambil dari hasil tanah mereka. Kitab Perjanjian Lama menjelaskan persembahan persepuluhan diberikan kepada orang Lewi (Bil. 18:21), dan dalam Ibrani 7:5 bahwa anak-anak Lewi yang menerima jabatan Imam menerima persepuluhan itu. Sebab orang Lewi berdasarkan sifat kedudukan dan tugas mereka dalam masyarakat Israel, tidak mempunyai mata pencaharian atau harta warisan untuk menjamin kehidupan mereka, maka untuk membalas pekerjaan yang mereka lakukan yaitu pekerjaan di Kemah Suci mereka menerima persepuluhan yang dipersembahkan oleh bangsa Israel (Bil. 18:21, 24). ${ }^{8}$

\footnotetext{
${ }^{5}$ Matthew Herry, Tafsiran Kitab Kejadian, (Surabaya : Momentum Christian Literature, 2014), 123

${ }^{6}$ Ibid., 124

${ }^{7}$ Ibid., 226

${ }^{8}$ J.G.S.S. Thomas, Ensiklopedi Alkitab Masa Kini Jilid II, (Jakarta : Yayasan Bina Kasih/OMF, 2000), 252
} 
Memberi persembahan kepada Tuhan harus dengan hati yang sungguh-sungguh, sebab dalam 2 Korintus 9:7 menjelaskan bahwa masing-masing memberi menurut kerelaan hatinya. Secara harafiah menjelaskan bahwa setiap orang yang memberi persembahan harus memberi sesuai dengan apa yang diputuskan dari hati. Selanjutnya dalam memberikan persembahan jangan dengan sedih hati atau dengan paksaan, hal ini berarti perasaan sedih atau menyesal karena melakukan sesuatu yang tidak ingin dilakukan, atau dipaksa dari dalam hati sendiri atau pun ditekan oleh orang-orang yang memaksa melakukan sesuatu yang tidak ingin dilakukan.Tetapi dalam memberi persembahan harus dilakukan dengan sukacita sebab Allah mengasihi orang yang memberi dengan sukacita. ${ }^{9}$

\section{SIKAP MEMBERI PERSEMBAHAN}

\section{MENURUT INJIL MARKUS 12:41-44}

Penulis Injil Markus tidak disebut dalam Injil Markus, sama halnya dengan ketiga kitab Injil. Sama halnya yang diungkapkan oleh Drane bahwa pemberian nama Matius, Markus, Lukas, dan Yohanes secara tradisional merupakan pendapat jemaat dan bukan suatu klaim dari para penulisnya sendiri. ${ }^{10}$ Menurut tradisi Yohanes, Markus keturunan dari satu keluarga di Yerusalem. Ada pendapat yang berkenyakinan menyatakan bahwa yang menulis Injil Markus adalah Markus. ${ }^{11}$ Menurut Graham Swift Bapa-bapa Gereja diantaranya Papias, Justin, Martyr, Ireaneus, Clement dari Alexandria, Tertulianus, Origenes, Eusebius, dan Joreme penulisnya adalah Markus. ${ }^{12}$

Duyverman mengatakan bahwa, "maksud dari Injil ini adalah untuk memproklamirkan kabar baik tentang kemenangan Allah atas segala kuasa jahat, yang diwujudkan di dalam oleh Tuhan Yesus. Hal ini berlaku untuk seluruh dunia, tetapi terutama tertuju kepada bukan orang Yahudi. ${ }^{13}$ Tema utama dari Injil Markus adalah Yesus sebagai hamba. Dalam Injil Markus ini dapat dilihat pekerjaan Tuhan Yesus, setelah menyeleaikan suatu pekerjaan yang lain. Injil ini menceritakan bagaimana hamba Allah bekerja. $^{14}$

\footnotetext{
${ }^{9}$ Roger L. Omanson dan John Ellington, Pedoman Penafsiran Alkitab 2 Korintus, (Jakarta : Yayasan Karunia Bakti Budaya Indonesia, 2013), 199

${ }^{10}$ John Drane, Memahami Perjanjian Baru, (Jakarta : BPK Gunung Mulia, 2005), 208

${ }^{11}$ Carles f. Pfeiffer, Tafsiran Alkitab Wyeliffe jilid III (Jarkarta : Gandum Mas, 2006), 135

${ }^{12}$ C.E. Graham Swift, Markus dalam Donald Guthrie (at.al)..., 123.

${ }^{13}$ M.E. Duyveman, Pembimbing kedalam Perjanjian Baru, (Jakarta : BPK Gunung Mulia, 1980), 50

${ }^{14}$ Alpheus Khumalo, Stewart Snook dan Richard Jordahl, Penyelidikan Perjanjian Baru, (Bandung : Yayasan Kalam Hidup, 1997), 87.
} 
Pada tahun 60-an M, orang percaya diperlakukan secara kecam oleh masyarakat dan banyak diantaranya disiksa bahkan dibunuh dibawah pemerintah Kaisar Nero. Menurut tradisi para syahid Kristen di Roma itu terdapat Rasul Petrus dan Rasul Paulus. Salah seorang pimpinan gereja di Roma, Yohanes Markus digerakkan oleh Roh Kudus untuk menuliskan Injil ini sebagai suatu antisipasi yang bersifat nubuat atau tanggapan penggembalaan terhadap masa penganiayaan ini. Tujuannya ialah memperkuat dasar dasar iman dalam orang percaya di Roma dan jikalau diperlakukan, mendorong, mereka untuk dengan setia menderita demi Injil, dengan menghadapkan kepada mereka kehidupan, penderitaan, kematian serta kebangkitan Yesus Tuhan mereka. ${ }^{15}$

Latar belakang Injil Markus 12:41-44 yaitu Yesus menyebutkan sejumlah hal yang membuktikan bahwa ahli Taurat mengerjakan sesuatu agar dilihat oleh orang lain. Tujuan Yesus disini bukan untuk mengecam ahli-ahli Taurat namun Dia mengingatkan muridmurid-Nya supaya mereka tidak mengikuti ajaran mereka tingkah laku mereka. Yesus juga mengkritik ajaran mereka tentang Mesias (Mrk. 12:35-37) dan juga mengkritik ajaran orang Saduki yang tidak percaya akan adanya kebangkitan. Jadi tujuan utama dalam teks ini yaitu mengajak para pengikut Yesus supaya mereka tidak terpengaruh terhadap sikap dan ajaran ahli-ahli Taurat dan juga orang Saduki.

\section{Kajian exegetis Injil Markus 12:41-44}

Pada bagian ini penulis akan mengexesegese beberapa kata penting untuk mendapatkan kajian yang mendalam sehingga dapat memahami sikap memberi persembahan menurut Injil Markus 12:41-44.

Setelah Yesus memperhatikan dan mengamati orang-orang kaya dan janda miskin yang memberikan persembahan di Bait Allah, Dia juga memperhatikan sikap orang kaya dan janda miskin dalam memberi persembahan. Jadi pada ayat 41 sampai 42 menjelaskan tentang sikap orang-orang kaya dan janda miskin dalam memberi persembahan antara lain

\section{Orang Kaya Memberi Dengan Jumlah Yang Besar (Ayat 41)}

Memberi dalam bahasa Yunani memakai kata $\beta \alpha \lambda \lambda \omega$ (ballo) dalam bentuk verb indicative present active orang ketiga singular (kata kerja yang sedang dilakukan dengan cara aktif artinya melempar, membuang, menebarkan, menghamburkan, menjatuhkan, menerjunkan, meletakkan, membaringkan, membawa, menyemburkan, memasukkan,

\footnotetext{
${ }^{15}$ Donal C. Stamps, Alkitab Penuntun Hidup Berkelimpahan, (Malang : Gandum Mas, 2006), 1578
} 
memukul, mengayunkan. ${ }^{16}$ Sedangkan jumlah yang besar dalam bahasa Yunani memakai kata $\pi \lambda \varepsilon ı \omega \mathrm{v}$ (pleion), $\pi \lambda \varepsilon ı \mathrm{v}$ (pleion), atau $\pi \lambda \varepsilon \dot{o v}$ (pleou) artinya lebih banyak, lebih besar, kebanyakan, yang lain, sisanya, yang bermacam-macam. ${ }^{17}$ Jadi pada ayat 41 ini menunjukkan bahwa persembahan yang diberikan oleh orang-orang kaya di Bait Allah lebih banyak dari pada persembahan yang lain bahkan mereka memberi persembahan yang bermacam-macam.

Pengertian lain dari jumlah yang besar pada ayat ini menujukkan bahwa banyak orang kaya yang memberi banyak kepingan uang logam ke dalam peti persembahan. Pada bagian ayat ini dapat juga diterjemahkan bahwa banyak orang kaya memasukkan atau memberikan uang banyak. ${ }^{18}$ Memberi dengan jumlah yang besar pada ayat $41 \mathrm{~b}$ ini menunjukkan sikap orang kaya dalam memberi persembahan artinya bahwa mereka memberi persembahan lebih banyak dari yang lain.

Sikap Tuhan Yesus juga pada ayat 41 ini yaitu memperhatikan orang-orang kaya memasukkan uang yang banyak. Yesus juga tidak hanya melihat mereka pada saat memasukkan uang tetapi Ia juga juga memperhatikan memasukkan uang tersebut dengan jumlah yang besar. Tujuan Yesus disini yaitu mengajak para murid untuk memperhatikan bagaimanam sikap orang-orang dalam memberikan persembahan tersebut. ${ }^{19}$

Selain penjelasan di atas ayat 42 juga menjelaskan bahwa ada sejumlah besar orang kaya dan satu orang janda miskin. Orang kaya itu memberi jumlah yang besar sedangkan janda miskin memberi hanya dua peser yaitu satu duit. Persembahan janda miskin itu tidak melebihi beberapa rupiah dan uang receh yang diberikannya terletak dilantai Bait Allah diantara dari keeping-keping uang yang besar. ${ }^{20}$

\section{Janda Miskin Memasukkan Dua Peser (Ayat 42)}

Pada ayat 42 ini Yesus menjelaskan bahwa janda miskin memberikan persembahan hanya dua peser dan uang logam seperti ini disebut lepton yang secara harafiah bermakna logam yang tipis. Diantara semua logam yang ada inilah yang terkecil meskipun demikian Yesus berkata bahwa persembahan janda tersebut yang sangat kecil itu justru lebih besar dari pada semua persembahan yang lain sebab orang lain dengan mudah apa yang dapat

\footnotetext{
${ }^{16}$ Hasan Sutanto, Perjanjian Baru Interlinear Yunani-Indonesia dan Konkodansi Perjanjian Baru Jilid I..., 140

${ }^{17}$ Ibid..., 660

${ }^{18}$ Roger L. Omanson dan John Ellington,Penafsiran Alkitab Injil Markus...,508

${ }^{19}$ Matthew Henry, Tafsiran Injil Markus., 286

${ }^{20}$ Jakob Van Bruggen, Markus Injil Menurut Petrus., 443-444
} 
mereka simpan, sementara itu yang ada pada mereka masih banyak lagi yang tersisa. Sedangkan janda miskin ini telah memberikan semua yang dimilikinya. ${ }^{21}$

Kisah persembahan dua peser dari seorang janda miskin sangatlah mengherankan alasannya tentu saja karena mendapatkan perhatian khusus dari Tuhan Yesus, tidak biasanya Yesus memperhatikan jumlah persembahan melainkan kualitasnya. Namun pada bagian ini Yesus membicarakan bukan hanya kualitas pemberian janda itu tetapi juga kuantitas pemberiannya. Selain itu jumlah pemberian janda tersebut tidak seberapa dalam ukuran pada umumnya. Besarnya dua peser persembahan janda miskin itu adalah satu peser dalam mata uang Yahudi disebut satu lepton, dalam mata uang Yunani satu leptos, dalam mata uang Roma 0,5 (nol koma lima) Quadrans, kemudian dalam mata uang Amerika US\$ 0,25 (nol koma dua lima), sen, sedangkan dalam rupiah nilainya ini sama dengan Rp. 2.500 (dua ribu lima ratus) dengan asumsi kurs 1 US\$ sama dengan Rp.10.000 (sepuluh ribu rupiah) jadi dua peser dalam rupiah sekitar 5.000 (lima ribu). ${ }^{22}$

Bagi janda miskin nilai itu sangat besar dan pada masa itu nilai uang tersebut sama dengan upah pekerja sehari artinya janda miskin telah memberikan seluruh penghasilannya pada hari itu dan seluruh biaya hidupnya sehari. Inilah yang menarik perhatian Yesus bukan saja nilai rupiahnya, melainkan nilai hati yang memberikannya. Nilai rupiahnya sangat kecil bagi orang lain yang berpenghasilan besar tetapi bagi janda miskin nilai itu sangat besar. Dia juga memberikan seratus persen dari miliknya bukan sepuluh persen artinya dia memberi dari kekurangannya yaitu seluruh nafkahnya (Mrk. 12:44). ${ }^{23}$

Dua peser dalam bahasa Yunani menggunakan kata $\lambda \varepsilon \pi \tau o v$ (lepton) yang berasal dari kata $\lambda \varepsilon \pi \tau o ́ \varsigma$ (leptos) artinya uang logam kecil tembaga yang bernilai 1/128 dari upah rata-rata sehari. ${ }^{24}$ Jadi dua peser pada ayat 42 ini menunjukkan nilai persembahan janda miskin yang diberikan di Bait Allah. Selain itu dua peser dapat diartikan satu duit dalam Bahasa Indonesia Masa Kini menerjemahkan dua uang tembaga yaitu uang receh yang terkecil nilainya. Ungkapan ini dapat diterjemahkan menjadi dua uang logam yang kecil yang nilainya sedikit atau kecil sekali atau dua keping receh yang paling kecil nilainya. Ayat ini menunjukkan bahwa jumlah uang yang diberikan oleh perempuan miskin itu

\footnotetext{
${ }^{21}$ William Barclay, Pemahaman Alkitab Setiap Hari Injil Makus, (Jakarta : BPK Gunung Mulia, 2008), 503-504

${ }^{22}$ BIngman Sirait, Menjadi Manusia Sempurna, (Jakarta : BPK Gunung Mulia, 2011), 179

${ }^{23}$ Ibid., 180

${ }^{24}$ Hasan Sutanto..., 485
} 
sangat kecil. Jadi ayat ini menunjukkan bahwa jaumlah uang yang diberikan oleh perempuan miskin itu sedikit sekali. ${ }^{25}$

Berdasarkan penjelasan di atas penulis menyimpulkan bahwa persembahan janda miskin hanya dua logam atau dua keping receh yang nilainya sangat kecil. Meskipun nilainya kecil, tetapi janda miskin tersebut mempunyai hati yang ikhlas untuk memberikan persembahan. Selain itu jumlah persembahan janda miskin sangat berbeda dengan persembahan orang kaya, sebab dia hanya memberi persembahan dengan nilai yang sangat kecil dibandingkan dengan persembahan orang-orang kaya, jadi persembahan janda miskin hanya lima ribu rupiah.

Selain itu pada ayat 42 menjelaskan bahwa janda miskin yang memasukkan uang peser yaitu seluruh nafkahnya dan Yesus pun sangat memuji janda tersebut. Ia juga memanggil murid-murid-Nya dan memberitahukan kepada mereka bahwa janda miskin ini sangat berusaha untuk menabung apa yang telah diberikannya itu. Artinya apa yang dimiliki janda tersebut hampir tidak cukup bagi dirinya sendiri, semuanya yang ada padanya yang bisa dipakainya untuk memenuhi kehidupannya setiap hari, dan mungkin juga merupakan sebagian besar nafkah yang diperolehnya dari hasil pekerjaan sebelumnya. Berdasarkan penjelasan tersebut maka Kristus mengetahui bahwa janda miskin tersebut sungguh-sungguh memberi dan Ia juga memperhitungkan bahwa apa yang telah janda tersebut melebihi semua apa yang dimasukkan orang-orang kaya itu sebab mereka semua memberi dari kelimpahannya tetapi janda miskin ini memberi dari kekurangannya. ${ }^{26}$

\section{Penilaian Tuhan Yesus}

Setelah Yesus memperhatikan dan memperhatikan bagaimana sikap orang kaya dan janda miskin dalam memberi persembahan. Penilaian Yesus tidak hanya tertunjukkan pada jumlah persembahan yang diberikan oleh orang-orang kaya dan juga janda miskin. Namun Ia juga menilai bagaimana sikap mereka dalam memberi persembahan itu. Yesus juga tidak hanya menilai dari luar saja tetapi Ia juga melihat dari dalam yaitu sikap hati orang yang memberi persembahan di Bait Allah.Jadi pada ayat 43 sampai ayat 44 menjelaskan tentang penilaian Tuhan Yesus terhadap persembahan orang-orang kaya dan juga janda miskin. Ada tiga penilaian Yesus terhadap persembahan tersebut antara lain :

\section{Janda Miskin Memberi Lebih Banyak (Ayat 43)}

Penilain Yesus yang pertama yaitu janda miskin memberi lebih banyak dibanding dengan orang-orang yang yang memberi banyak persembahan. Pada ayat 43 sampai

\footnotetext{
${ }^{25}$ Roger L. Omanson dan John Ellington,Penafsiran Alkitab Injil Markus ...,508

${ }^{26}$ Matthew Henry, Tafsiran Injil Markus., 286
} 
dengan 44 menjelaskan bahwa persembahan janda miskin lebih banyak dibandingkan dengan persembahan orang kaya. Janda miskin tersebut telah memberikan seluruh nafkahnya yang ada pada saat itu, sedangakan persembahan yang diberikan oleh orangorang kaya itu sesungguhnya bukan persembahan sebab cukup banyak uang yang tersisa pada mereka. Sedangkan bagi janda miskin ini persembahan itu sebuah pengorbanan sebab ia telah memberikan seluruh nafkahnya dari kemiskinannya itu artinya segala yang dimilikinya dipersembahkannya kepada Tuhan. Janda tersebut memberi lebih banyak bukan atas diperhitungan atau nilai tetapi atas dasar dorongan yang timbul dalam hatinya. Pada bagian ini orang-orang kaya dalam keserakahannya itu dahadapkan pada suatu contoh dalam kesediaan dalam memberi persembahan seperti yang telah ditunjukkan janda miskin tersebut.Ia juga telah melepaskan diri dari segala miliknya dan memberikannya untuk pelayanan kepada Allah. Calvin mengatakan bahwa Tuhan sangat memuji kesederhanaannya sebab ia telah melupakan semua kebutuhannya sendiri untuk membuktikan bahwa ia mengasihi Tuhan. ${ }^{27}$

Berdasarkan perkataan Yesus yang tercantum pada ayat 43 dan 44 janda tersebut memberi lebih banyak dari semua orang, sebab ia memberi dari kekurangannya. Semua yang dimilikinya yaitu seluruh nafkahnya dapat disimpulkan bahwa semangat janda tersebut untuk memberi sumbangan sangat luar biasa. ${ }^{28}$ Selain itu pada ayat 44 janda miskin bersikap luar biasa sebab dia memberikan apa yang diperlukannya dan inilah yang harus dipahami oleh murid-murid Yesus. Markus tidak menyajikan suatu ajaran moral khususnya dalam teks ini, namun pengikut Yesus dapat mengambil kesimpulan dari ajaran tersebut.Pertama jangan menilai orang dan tindakannya dari sudut lahiria saja. Kedua orang yang paling dermawan dan yang paling saleh belum tentu mereka memiliki sikap janda miskin tersebut. Ketiga Allah sendiri mengetahui hal-hal tersembunyi dan mengenal hati manusia. Keempat yang paling menentukan nilai seseorang ialah motivasi atau dorongan hati artinya jika sedekah atau persembahan diberikan dengan motivasi atau dorongan yang murni dan merupakan gerakan kasih serta penyangkalan diri maka persembahan tersebut dihargai oleh Allah (Mrk. 9:41; 10:21). ${ }^{29}$

\section{Orang Kaya Memberi Dari Kelimpahan (Ayat 44)}

Kelimpahan dalam bahasa Yunani memakai kata $\pi \varepsilon \rho ı \sigma \varepsilon \varepsilon v ́ o v \tau o \zeta$ (perisseuontos) yang berasal dari kata $\pi \varepsilon \rho ı \sigma \sigma \varepsilon v ́ \omega$ (perisseuo). Kata ini menggunakan bentuk verb

\footnotetext{
${ }^{27}$ M.H. Bolkostein, Kerajaan Yang Terselubung, (Jakarta : BPK Gunung Mulia, 2005), 253

${ }^{2828}$ Stefan Leks, Tafsiran Injil Markus., 400

${ }^{29}$ Stefan Leks, Tafsiran Injil Markus., 400
} 
participle present active genitive neuter singular (kata kerja pertisipasi yang dilakukan sekarang dengan cara aktif yang hanya di miliki oleh satu orang. Artinya berlebihan, berkelebihan, berlimpah-limpah, bertambah, maju, ada keuntungan, melimpahkan, membuat bertambah. ${ }^{30}$ Pengertian lain dari kelimpahanmenunjukkan keadaan harta milik yang lebih dari cukup yang berlimpah. Jadi orang-orang kaya memberikan hanya sebagian kecil dari harta milik mereka yang berlimpah. Dalam pengertian lain bahwa mereka mempunyai uang lebih dan memberikan sebagian dari uang lebihnya itu. ${ }^{31}$

\section{Janda Miskin Memberi Dari Kekurangan (Ayat 44)}

Kekurangan dalam bahasa Yunani menggunakan kata v́ $\tau \varepsilon \rho \eta ́ \sigma \varepsilon \omega \varsigma$ (hustereseos)

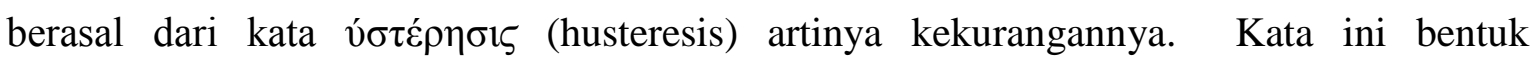
nominative feminine genitive singular (kata ganti orang yang menunjukkan kepada perempuan). ${ }^{32}$ Istilah Yunani dari kekurangan ini menunjukkan keadaan orang yang sangat miskin. Pengertian lain bahwa kebutuhannya dasarnya sama sekali tidak tercukupi dan juga memerlukan bantuan dari orang lain. Jadi dalam begian ini janda miskin tidak memberikan persembahan dari kekurangaanya tetapi seluruh nafkahnya dipersembahkannya kepada Tuhan.Jadi janda miskin ini memberikan sesuatu yang sebenarnya sangat diperlukan untuk kebutuhan setiap hari. Rupanya Yesus ingin menunjukkan bahwa janda miskin mempunyai hati yang sungguh-sungguh untuk memberi persembahan.Meskipun janda tersebut sangat miskin, tetapi semua yang dimilikinya tetap dia persembahkan kepada Tuhan. ${ }^{33}$

Jadi dapat disimpulkan bahwa janda miskin memberi persembahan bukan karena ia memiliki harta, tetapi ia mempunyai hati untuk memberi kepada Tuhan. Selain itu janda miskin memberi persembahan dari kekurangannya artinya dalam keterbatannya ia belajar untuk memberi. Janda miskin juga tidak hanya memberikan persembahan secara materi namun ia menyerahkan seluruh nafkahnya sebagai persembahan kepada Tuhan. Memberi dari kekurangan dapat juga diartikan pemberian seseorang ditentukan bukan jumlah uang yang diberikan, tetapi oleh oleh jumlah pengorbanan yang terlibat dalam pemberian itu. Seringkali orang kaya hanya memberi dari kekayaanya, tetapi pemberian janda miskin ini menuntut segalanya dari padanya.

\footnotetext{
${ }^{30}$ Hasan Sutanto...,632

${ }^{31}$ Roger L. Omanson dan John Ellington,Penafsiran Alkitab Injil Markus...,510

${ }^{32}$ Hasan Susanto...,785

${ }^{33}$ Roger L. Omanson dan John Ellington,Pedoman Peneafsiran Alkitab Injil Markus..., 510
} 


\section{Kajian Theologis}

Setelah mengeksegese beberapa kata penting untuk mendapatkan kajian yang mendalam sehingga dapat memahami sikap memberi persembahan menurut Injil Markus 12:41-44, penulis juga memaparkan beberapa kajian teologis untuk memahami sikap memberi persembahan berdasarkan penilaian Yesus antara lain :

\section{Sikap Memberi Persembahan Berdasarkan Penilaian Yesus}

Memberi persembahan harus memiliki mata yang tertuju kepada Tuhan artinya memberi persembahan bukan untuk dilihat oleh orang lain tetapi untuk kemuliaan Tuhan. Apabila memberikan yang terbaik kepada Tuhan melalui persembahan itu semua menunjukkan bentuk penyerahan diri kepada-Nya. Memberi merupakan ungkapan yang luar biasa dari komitmen hati kepada Allah dan memberi yang terbaik dan yang pertama kepada Tuhan merupakan penyataan paling jelas yang menunjukkan "apa yang menjadi milikku sekarang menjadi milik-Mu" artinya apa yang menjadi milik seseorang harus dikembalikan kepada Tuhan melalui persembahan. ${ }^{34}$

Penjelasan di atas memaparkan bahwa memberi persembahan kepada Allah merupakan bentuk penyerahan diri dihadapan-Nya artinya bahwa persembahan tersebut bukan hanya menunjukkan kepada materi atau harta, tetapi juga menunjukkan kepada hidup setiap hari. Persembahan yang terbaik dan yang berkualitas yaitu persembahan yang diberikan dengan sepenuh hati dan tidak bersungut-sungut.Sehubungan dengan itu maka sikap yang baik dalam memberi persembahan yaitu memberi dengan mata tertuju kepada Tuhan dan memberi dengan hati yang sungguh.

Sikap lain dalam memberi yaitu Matius 6:3-4 "tetapi jika engkau memberi sedekah, janganlah diketahui tangan kirimu apa yang diperbuat tangan kananmu. Hendaklah sedekahmu itu diberikan dengan tersembunyi, Bapamu yang melihat yang tersembunyi akan membalaskan kepadamu." Maksud dari ayat ini yaitu memberi sedekah atau persembahan jangan pernah diberitahukan kepada orang lain, tetapi jika memberi seseatu harus diberikan dengan sikap kasih dan dengan hati yang tulus. Jadi berikut ini penulis akan memaparkan sikap memberi persembahan berdasarkan penilaian Yesus.

\section{Janda Miskin Memberi Lebih Banyak (Ayat 43)}

Ayat 43 ini merupakan penilaian Yesus terhadap persembahan janda miskin yang menjelaskan bahwa janda miskin memberi lebih banyak dibandingkan dengan orang-orang kaya. Yesus menilai persembahan tersebut sebagai persembahan yang lebih besar

\footnotetext{
${ }^{34}$ Bennny Hinn, Jalan Alkitabiah Menuju Berkat, (Jakarta : Imanuel Publishing House, 2006), 113
} 
dibandingkan dengan persembahan yang lainnya, sebab meskipun jumlah persembahan janda tersebut nilainya sangat kecil namun jumlah tersebut persembahan tersebut merupakan keseluruhan dari penghasilannya sehingga maknanya sangat besar. Sikap yang terpenting yang ditunjukan janda tersebut ialah meskipun jumlah persembahannya sangat kecil, tetapi ia tidak merasa terganggu terhadap orang lain yang mampu memberi persembahan dengan nilai yang sangat besar. Kemudian bagi janda tersebut ketulusan hati jauh lebih penting dari pada sekedar jumlah sehingga Yesus memberikan penilain yang sangat besar sebab ia mampu memberi dari kekurangannya. Peristiwa ini sesungguhnya menyangkut mental, motivasi, ketulusan dan kejujuran hati seseorang yang ingin berkorban untuk memberi persembahan. Hal tersebut terbukti bahwa janda tersebut memiliki keberanian untuk menunjukkan identitasnya ditengah-tengah orang banyak yang mampu memberi persembahan, sehingga Yesus mengatakan bahwa memberi dari dari kekurangan jauh lebih bermakna dari kelebihan. Melalui peristiwa ini Yesus mengingatkan murid-murid-Nya agar dalam pelayanan mereka tidak terjebak oleh penampilan seseorang. ${ }^{35}$

Berdasarkan penjelasan tersebut dapat disimpulkan bahwa persembahan janda miskin lebih banyak bukan karena nilai, namun ketulusan hatinya dalam memberi persembahan itu. Selain itu maksud Yesus dalam bagian ini bukan nilai persembahan yang lebih besar tetapi persembahan tersebut mempunyai makna yang sangat besar. Yesus juga mengajak para murid dan pera pengikut-Nya juga agar mereka memperhatikan sikap janda tersebut yang ingin berkorban dalam memberi persembahan. Jadi yang lebih besar yang dimaksud Yesus yaitu bukan nilai persembahan tetapi maknanya.

\section{Orang Kaya Memberi Dari Kelimpahan (Ayat 44)}

Persembahan orang-orang kaya sangat berbeda dengan persembahan janda miskin baik dari segi kwantitatif maupun kwalitatifnya. Pada ayat 41 sampai dengan 44 menjelaskan tentang bagaimana sikap orang kaya dan janda miskin dalam memberi persembahan. Orang kaya memberi persembahan dengan jumlah yang sangat besar sedangkan janda miskin hanya memberikan dua peser dan nailainya sangat kecil. Persembahan janda miskin pada waktu itu hanya cukup untuk memenuhi kebutuhan dalam sehari, namun dia dengan rela hati memberikan semunya sebagai persembahan kepada Tuhan. Berdasarkan penilaian Yesus persembahan janda miskin tersebut lebih banyak dibandingkan dengan persembahan orang kaya, sebab mereka memberi sesuai dengan apa

${ }^{35}$ Elisa B. Surbakti, Benarkah Yesus Juruselamat Universal (Jkarta : BPK Gunung Mulia, 2005), 85 
yang disisihkan dari kekayaan mereka, tetapi janda tersebut telah memberikan semua apa yang dimilikinya yaitu seluruh nafkahnya. ${ }^{36}$

Yesus tidak menilai persembahan orang-orang kaya dengan nilai yang besar meski pun persembahan mereka lebih banyak dibandingkan dengan persembahan janda miskin, sebab mereka hanya memberikan dari kelimpahan harta mereka. Pengertian lain bahwa persembahan mereka tidak sesuai dengan harta yang dimiliki. Selain itu juga mereka memberi persembahan bukan karena kerelaan hati tetapi oleh karena mereka memiliki harta yang banyak. Tujuan mereka juga supaya orang lain mengetahui bahwa mereka mampu memberi persembahan. Itulah sebabnya Yesus tidak menilai persembahan merekan menjadi lebih banyak, pengertian lain bahwa persembahan orang-orang kaya tidak berkenan kepada Tuhan.

\section{Janda Miskin Memberi Dari Kekurangan (Ayat 44)}

Ayat 44 ini merupakan penilaian Yesus terhadap persembahan janda miskin dan Yesus berkata bahwa persembahannya tersebut lebih banyak dibandingkan dengan persembahan yang lain sebab ia memberikan dari kekurangannya. Sikap seorang janda miskin ini yang memberi dari kekurangan merupakan contoh yang ditunjukan oleh Yesus kepada para murid dan juga kepada orang banyak. Tujuan Yesus untuk menunjukan bahwa janda miskin tersebut memberi persembahan dari kekurangannya bukan dari kelebihannya akhirnya Yesus menilai bahwa persembahan itu lebih banyak. Sesungguhnya janda tersebut membutuhkan uang tetapi oleh karena ketulusan hati ia rela memberi persembahan dari penghasilannya itu. Pengertian lain bahwa janda miskin tersebut memberi bukan karena sisa kesungguhan hati dari perjuangannya yang berat. Jadi memberi dari kekurangaan dapat diartikan bahwa meskipun orang Kristen belum kecukupan tetapi harus mempunyai kerelaan hati untuk memberi sebab itulah yang dilakukan oleh jemaat mula-mula. Mereka saling memberi dari kekayaan kepada orang lain akibatnya diantara mereka tidak ada yang kekurangan. ${ }^{37}$

Alkitab juga menjelaskan bahwa segala harta milik harus dipakai untuk menolong sesama dan itulah yang dilakukan oleh orang Samaria yang murah hati (Luk. 10:30-35). Sikap orang Samaria bukan memberikan segala sesuatu melainkan menyediakan dana agar orang yang jatuh ke dalam tangan perampok-perampok dapat diselamatkan dan dirawat sampai sembuh. Unsur yang terpenting dalam bagian ini ialah bahwa harta dunia harus dipergunakan untuk pelayanan kasih dan sehubungan peristiwa ini bukan jumlah

\footnotetext{
${ }^{36}$ Rex A. Pai, Harta Karun Dalam Doa, (Yogyakarta : Kanisius, 2009), 251

${ }^{37}$ Paul Suparno, Saat Jubah Bikin Gereh, (Yogyakarta : Kanisius), 149
} 
pemberian yang diperhitungkan tetapi sikap hati. Begitu juga janda miskin yang memiliki uang dua peser tetapi ia mempunyai hati untuk memberi persembahan, bahkan persembahannya tersebut mempunyai makna dan nilai yang sangat besar (Mark. 12:43). Meski pun secara secara kwantitatif pemberian janda miskin tersebut sedikit namun secara kwalitatif pemberiaannya lebih besar. ${ }^{38}$

\section{Tujuan Memberi Persembahan}

Kitab Perjanjian Lama juga mengatur dengan sangat ketat mengenai kewajiban umat Israel untuk memberikan persembahan dan membayar persepuluhan dengan tepat yaitu persepuluh dari hasil usaha pekerjaan mereka. Persembahan tersebut yang diberikan untuk menjadi nafkah bagi kaum lewi dan para Imam yang melayani mereka dalam ibadah kepada Tuhan. Apa bila seluruh umat Israel taat melaksanakan semua perintah Tuhan dalam perjanjian Tuhan, termasuk melaksanakan kewajiban membayar persepuluhan maka Tuhan memberkati mereka sehingga baik para imam, orang-orang lewi, maupun seluruh umat pada umumnya tidak berkekurangan dalam hal makanan, pakaian, keamanan dan kesejahteraan pada umumnya. Maksud lain dari perpuluhan tersebut yaitu agar para Imam dan orang-orang Lewi tinggal menyebar di antara suku-suku lain di seluruh wilayah Israel, untuk mengajar umat Israel mempelajari Hukum Taurat, dan mantaatinya. ${ }^{39}$

Selain itu persembahan persepuluhan dalam Perjanjian Lama berkaitan dengan pemeliharaan kesejahteraan hidup para Imam dan orang-orang Lewi sebab mereka tidak memiliki bagian tanah pusaka sebagaimana suku-suku Israel lainnya. Kitab Perjanjian Baru menjelaskan bahwa para Imam dan orang-orang Lewi sebagai pemimpin ibadah, pemimpin pujian, pengajar Hukum Taurat dan pemelihara tempat ibadah tidak disyaratkan lagi. Jadi persembahan-persembahan yang dimaksudkan untuk memelihara kehidupan mereka juga tidak diharuskan. Tetapi yang dijelaskan dalam Perjanjian Baru dalam bentuk uang adalah persembahan suka rela untuk pelayanan diakonia atau pelayanan kasih khususnya bagi orang-orang miskin. Persembahan yang sesungguhnya dituntut dalam Perjanjian Baru yaitu tubuh, segala sesuatu milik seseorang bahkan nyawa seseorang tersebut harus dipersembahkan sebagai persembahan yang hidup, kudus dan yang berkenan kepada Allah. ${ }^{40}$

Penjelasan di atas memberikan pemahaman bahwa segala sesuatu yang dimiliki oleh setiap orang harus dipersembahan kepada Tuhan sebagai kemuliaan-Nya. Selain itu

\footnotetext{
${ }^{38}$ Hen ten Napel, Jalan Yang Lebih Utama Etika Perjanjian Baru, (Jakarta : BPK Gunung Mulia, 2006), 53

${ }^{39}$ Christian Nur Rahadi, Perjanjian Baru, (Bandung : Revivang Publishing House, 2008), 20

${ }^{40}$ Ibid., 31
} 
berbicara dengan persembahan bukan masalah kecil atau besar tetapi memberikan persembahan harus memiliki motivasi yang benar dihadapan Tuhan. Jadi dalam memberi persembahan harus memiliki mata yang tertuju kepada Tuhan dan juga memiliki Tujuan yang benar.

Memberikan persembahan kepada Tuhan untuk kemuliaan-Nya menunjukkan bahwa persembahan tersebut merupakan tanda mengutamakan kerohanian yaitu keselamatan jiwa yang kekal. Motivasi dalam memberi persembahan akan menjadi ukuran apakah persembahan tersebut memuliakan Tuhan atau tidak. H. L. Senduk menyatakan "memberi persepuluhan bukan dengan tujuan untuk menjadi kaya melainkan oleh karena iman dan kasih dalam menaati Firman Tuhan. ${ }^{41}$ Tujuan lain memberi persembahan yaitu sebagai ucapan syukur kepada Tuhan (Ul. 8:18). Maksud dari ayat ini yaitu Allah adalah sumber segala sesuatu baik itu harta dan lainsebagainya. Jadi sebagai orang percaya atau umat Allah harus mengucap syukur kepada Tuhan melalui persembahan.

\section{Rangkuman}

Berdasarkan penjelasan di atas penulis menyimpulkan bahwa memberi persembahan merupakan perintah Tuhan. Memberi persembahan kepada Tuhan harus memberi yang terbaik sebab hal itu yang dikehendaki oleh Tuhan. Allah telah memberikan segala harta dan kekayaan bagi setiap orang sebab itu Allah memerintahkan supaya semuanya itu dipersembahkan kepada-Nya sebagai wujud ucapan syukur. Persembahan yang diberikan bukan berbicara tentang nilai tetapi kualitasnya dan motivasi dalam memberi persembahan tersebut. Kekayaan atau harta yang Allah berikan bagi setiap orang harus digunakan bukan hanya mementingkan diri sendiri namun digunakan untuk membantu orang lain dan terutama kemuliaan Tuhan. Paulus menjelaskan bahwa memberi persembahan harus dengan sukacita dan juga dengan rela hati sebab Allah mengasihi orang memberi dengan sukacita.

Memberi persembahan tidak sekedar menaati perintah Tuhan namun harus melakukannya sebagai wujud ucapan syukur kepada Tuhan, sebab Dialah sumber segala sesuatu. Selain itu yang harus diperhatikan dalam memberi yaitu motivasi dan tujuan yang benar dalam memberi, sebab memberi persembahan dengan motivasi yang benar akan menyenangkan hati Tuhan. Sikap hati nurani yang benar dalam memberi maka memberi banyak kepada Tuhan, sebab dari hati nurani itulah yang mendorong seseorang melakukan

\footnotetext{
${ }^{41}$ Ibid..., 78
} 
segala sesuatu. Seseorang yang sudah mempunyai komitmen dalam memberi maka orang tersebut memberi dengan sukacita artinya tidak bersungut-sungut atau dengan paksa. Selain itu seseorang yang sudah mengerti bahwa Allah sumber segala sesuatu, maka orang tersebut selalu memberi kepada Tuhan. Memberi persembahan juga harus sesuai dengan harta yang dimiliki artinya bahwa harta dan persembahan harus sesuai. Setiap orang yang memberi persembahan hendaknya memberi dengan sukacita dan juga dengan rela hati sebab kedua hal inilah yang mendorong seseorang dapat memberi persembahan. Persembahan yang diberikan dengan sukacita dan relahati memiliki makna yang sangat besar dimata Tuhan meskin nilai persembahan yang diberikan sangat kecil. Dasar memberi persembahan bukan harta atau kekayaan melainkan sikap hati yang timbul dalam diri seseorang. 


\section{DAFTAR PUSTAKA}

----. (2014). Alkitab Edisi Studi Jakarta : Lembaga Alkitab Indonesia

Barclay, William. (1991). Pemahaman Alkitab Setiap Hari Injil Matius 1-10, Jakarta: BPK Gunung Mulia.

Baxter, J. Sidlow. (1995). Menggali Isi Alkitab Jilid 3, Jakarta: Yayasan Komunikasi Bina Kasih/OMF.

Browning,W.R.F. (2011). Kamus Alkitab, Jakarta : BPK Gunung Mulia.

Bruggen,Jakob Van. (2011). Markus Injil Menurut Petrus, Jakarta: BPK Gunung Mulia.

Champion, Deni J. (1999). Metode dan Masalah Penelitian Sosial, Bandung: Rafika Aditama.

Darmaputera, Eka. (2012). Iman Dalam Perbuatan, Jakarta : BPK Gunung Mulia.

Drane, John. (2005). Memahami Perjanjian Baru, Jakarta: BPK Gunung Mulia.

Duyveman, M.E. (1980). Pembimbing kedalam Perjanjian Baru, Jakarta : BPK Gunung Mulia.

Graham Swift, C.E. (....). Markus dalam Donald Guthrie at.al

Hakh, Samuel Beyamin. (2010). Perjanjian Baru sejarah, pengantar dan pokok-pokok Teologisnya Bandung: Bina Media Informasi.

Hardius, Mustava Edwid. (2008). Proses Penlitian Kualitatif, Jakarta: Lembaga Penerbit FEUI.

Harris P. Nasution, R.S Nixo. (2013). Tafsiran Alkitab Masa Kini Matius-Wahyu, Jakarta : Yayasan Komunikasi Bina Kasih.

Henry, Matthew. (2007). Tafsiran Injil Markus, Surabaya: Momentum.

Heri Azwanto, Daniel Haryono. (2012). Kamus Besar Bahasa Indonesia, Jakarta : PT Media Pustaka.

Herry,Matthew. (2014). Tafsiran Kitab Kejadian, Surabaya: Momentum.

John, Stambaugh dan David, Balch. (2008). Dunia Sosial KeKristenan Mula-Mula, Jakarta : BPK Gunung Mulia.

Khumalo, Alpheus (at.al). (1997). Penyelidikan Perjanjian Baru, Bandung: Yayasan Kalam Hidup.

Leks, Stefan. (2007). Tafsiran Injil Markus, Yogyakarta: Kanisius.

Nazir, Muhamad. (2003). Metode Penelitian Jakarta : Gratia Indonesia. 
Ningrat, Kuncoro. (2003). Metodologi Penelitian Masyarakat, Jakarta : Gratia Indonesia.

Omanson, Roger L. dan Ellington, John. (2013). Pedoman Penafsiran Alkitab 2 Korintus, Jakarta : Yayasan Karunia Bakti Budaya Indonesia.

(2014). Penafsiran Alkitab Injil Markus, Jakarta : Lembaga Alkitab Indonesia dan Yayasan Kartidaya .

(2005). Pedoman Penafsiran Alkitab Injil Lukas, Jakarta : Yayasan Karunia Bakti Budaya Indonesia.

(2009). Pedoman Penafsiran Alkitab Surat Yakobus, Jakarta: Yayasan Karunia Bakti Budaya Indonesia.

(2005). Pedoman Penafsiran Alkitab Injil Lukas, Jakarta : Yayasan Karunia Bakti Budaya Indonesia

Pai, Rex A. (2009). Harta Karun Dalam Doa, Yogyakarta : Kanisius.

Pasaribu, Marulak. (2005). Eksposisi Injil Sinoptik, Malang: Gandum Mas.

Pfeiffer, Carles f. (2006). Tafsiran Alkitab Wycliffe jilid III Jarkarta : Gandum Mas

R.A Cole (et.al ). (2007). Injll Markus, Jakarta: BPK Gunung Mulia.

Salim, Peter. (...). The Comterporary English Indonesia Dictionary.

Sintoang, Nalom. (2005). Sabda Tuhan Masa Kini I, Jakarta : BPK Gunung Mulia.

Stambaugh John dan Balch David. (2008). Dunia Sosial KeKristenan Mula-Mula, Jakarta: BPK Gunung Mulia.

Stamps, Donal C. (2006). Alkitab Penuntun Hidup Berkelimpahan, Malang : Gandum Mas

Subandrijo, Bambang. (2010). Menyingkap Pesan-Pesan Perjanjian Baru, Bandung : Bina Media Informasi.

Sukamto. (2013). Kemiskinan sama dengan Kutuk?, Yogyakarta: Andi.

Surbakti, Elisa B. (2005). Benarkah Yesus Juruselamat Universal, Jakarta : BPK Gunung Mulia.

Sutanso, Hasan. (2006). Perjanjian Baru Interlinear Yunani-Indonesia dan Konkodansi Perjanjian Baru Jilid I, Jakarta : Lembaga Alkitab Indonesia.

Suyasno,Thomas. (2009). Memberi Makna Hidup, Jakarta : Prestasi Pustakaraya.

Thomas, J.G.S.S. (2000). Ensiklopedi Alkitab Masa Kini Jilid II, Jakarta : Yayasan Bina $\mathrm{Kasih} / \mathrm{OMF}$.

Winarno. (2004). Pengantar Penelitian Ilmu Dasar Metode Tekhnik, Bandung : Yayasan Kalam Hidup.

Wommanck, Andrew. (2013). Pengelolaan Keuangan, Publising. 
Zodhiates, Spiros. (1990). Hebraw-Greek Key Study Bible, Chattanooga : MG Publising 